\title{
Local distribution and abundance of Cardisoma guanhumi Latreille, 1928 (Brachyura: Gecarcinidae) in southern Brazil
}

\author{
Oliveira-Neto, JF. *, Batista, E., Metri, R. and Metri, CB. \\ UNESPAR - Universidade Estadual do Paraná, Campus Paranaguá \\ Rua Comendador Correia Junior 117, Centro, CEP 83203-560 Paranaguá PR \\ *jose.neto@fafipar.br
}

Received: March 1, 2012 - Accepted: January 22, 2013 - Distributed: February 28, 2014

(With 3 figures)

\begin{abstract}
The blue land crab, Cardisoma guanhumi Latreille, 1828 (Brachyura: Gecarcinidae) is officially included in the list of over-exploited species in Brazil, although still abundantly found in the state of Santa Catarina, the southern limit of its distribution. This species was found in forested areas, gardens, and grassy areas, including crabs with carapace width larger than $80 \mathrm{~mm}$. The existence of this population with these characteristics is surprising, since there is only one official record of the species in the southern region. The objectives of this study are to estimate the abundance and occupation patterns of C. guanhumi in this region. Correlations with conservation were discussed. The absolute abundance of crabs in the middle of summer activity was established for an area of $100,000 \mathrm{~m}^{2}$. A smaller area was mapped and divided into sampling units for statistical analyses. We distributed approximately 240 crabs in a forested area of about 3,000 $\mathrm{m}^{2}$ and $150 \mathrm{crabs}$ in grassy areas $\left(90,000 \mathrm{~m}^{2}\right)$. The statistical test of Kruskal-Wallis test showed that there are significant differences between the sizes of the openings of the galleries inside the forest and that located in grassy areas. In the forest, the openings tend to be much larger. Burrows were found at a distance of 150 metres from the channel. The number of galleries was higher in the forested area, although the burrows were more densely grouped in grassy areas. Although $C$. guanhumi seems to be adjusting well to changes caused by human occupation, small forested areas are more conducive to growth and conservation of this species.
\end{abstract}

Keywords: Gecarcinidae, blue-land-crab, Babitonga

\section{Distribuição local e abundância de Cardisoma guanhumi Latreille, 1928 (Brachyura: Gecarcinidae) no sul do Brasil}

\begin{abstract}
Resumo
O Guaiamum, Cardisoma guanhumi Latreille, 1828 (Brachyura: Gecarcinidae) é uma espécie oficialmente inclusa na lista de espécies sobre-explotadas no Brasil, ainda encontrada em abundância no Estado de Santa Catarina, seu limite austral de distribuição. Esta espécie foi encontrada tanto em áreas florestais quanto em jardins e áreas abertas, sendo comuns caranguejos de grande porte (largura da carapaça $>80 \mathrm{~mm}$ ). A existência dessa população com tais características surpreende, pois há apenas um registro oficial da espécie na região sul. Os objetivos deste estudo é estimar a abundância desta espécie na região, inferir padrões de distribuição relacionados ao tipo de ecossistema e ao tamanho das aberturas de toca. Essas informações foram relacionadas à conservação desta população. A abundância absoluta de caranguejos em atividade no meio do verão foi estabelecida para uma área de $100.000 \mathrm{~m}^{2}$. Uma área menor foi mapeada e dividida em unidades amostrais, utilizadas para análises estatísticas. Contamos aproximadamente 240 caranguejos distribuídos em uma área de floresta de aproximadamente $3.000 \mathrm{~m}^{2}$ e 150 caranguejos em áreas abertas equivalentes a $90.000 \mathrm{~m}^{2}$. O teste estatístico de Kruskal-Wallis evidenciou que há diferenças significativas entre os tamanhos das aberturas das galerias no interior da floresta em relação às localizadas em áreas abertas. Na floresta, as aberturas tendem a ser muito maiores. Foram encontradas tocas a uma distância de 150 metros do canal. O número de galerias foi maior na área florestada, embora as tocas sejam mais densamente agrupadas em áreas abertas. Embora C. guanhumi pareça estar se adaptando bem as mudanças provocadas pela ocupação humana, as pequenas áreas florestadas são mais propícias para o crescimento e a conservação desta espécie.
\end{abstract}

Palavras-chave: Gecarcinidae, guaiamum, caranguejo, Babitonga 


\section{Introduction}

The large blue land crab, Cardisoma guanhumi Latreille, 1828 (Brachyura: Gecarcinidae) lives in tropical and subtropical regions in Florida (USA), Bermudas, Gulf of Mexico, Central America, Antilleans and the east coast of South America (Melo, 1996; Hill, 2001; Wedes, 2004), in burrows located in the dryer periphery of mangrove areas, being very adapted to terrestrial life (Taissoun, 1974). An individual male can weigh up to $500 \mathrm{~g}$, and its carapace reaches $11 \mathrm{~cm}$ in length (Gifford, 1962). Over the Bahamas, the Caribbean and Puerto Rico, it is economically important, being explored extensively as a food resource (Hill, 2001; Lloyd, 2001; Hostetler et al., 2003; Rodriguez- Fourquet, 2002). In the U.S.A., it has not usually been exploited for food, but some people consider it a common garden pest in Florida (Hill, 2001). In Brazil, the species is often found being sold by street vendors (Oliveira, 1946) and in markets and fairs throughout the Brazilian northeastern coastal region (Oshiro et al., 1999; Oliveira et al., 2001) and exhibits considerable economic importance (Neto, 2011).

In some Brazilian regions, $C$. guanhumi has become rare, and the means of carapace length (CL) have been decreasing (Amaral and Jablonsky, 2005). Intense economical exploration is not viable, because the species is not abundant and grows slowly. Currently, C. guanhumi is officially considered an overexploited species in Brazil (Amaral and Jablonski, 2005; Brasil, 2005). The occurrence of $C$. guanhumi in Santa Catarina state was reported by Branco (1991), although the low abundance in that location suggested that this species is not common in southern Brazil. At a distance of 100 kilometres of its southern limit of distribution, C. guanhumi has been abundantly found on the drier banks bordering the Linguado channel, at Babitonga Bay, Santa Catarina state, southern Brazil. This population was used in genetic population studies that reveled that this population is neither historically isolated nor genetically distinct from populations of the northeastern and southeastern Brazil despite the great distances between them (Oliveira-Neto et al, 2008). Although Santa Catarina has a climate very different from northeastern Brazilian states, the species seems to be very adapted to the region, reaching frequently $11 \mathrm{~cm}$ of carapace width. The objectives of this study are to estimate the population density and distribution pattern of C. guanhumi in two ecosystems that are not typically associated to this species, and ascertain its abundance in the region. All this information was related to the conservation of this population.

\section{Methods}

\subsection{Study area}

The estuary of Linguado channel (26'24'29', S 48 37'09') is located at Babitonga bay, in the state of Santa Catarina (Figure 1). This location is very close to the southernmost geographic distribution register of this species according to Branco (1991), the Itacorubi mangrove, at Florianópolis, Santa Catarina state, at Latitude $27^{\circ} 35^{\prime}$ S.
Following the Köppen-Geiger system, this region has a Cfa (subtropical and humid) climate, with precipitation during all year (Peel et al., 2007).

The nearest three metres from the water are irregularly occupied by mangrove or sandbank plants. The most common plant species are Hibiscus pernanbucencis Arruda, Schinus terebinthifolius Raddi e Sophora tomentosa L. Most of the C. guanhumi population was found in a rain forest fragment located very close of the water of the Linguado channel, among many species of trees and lianas. The canopy reaches nearly ten metres in this case. We identified the most abundant species: Potomorphe umbellate (L.) and Piper sp. (Piperaceae), Ficus adhatodifolia Schott. (Moraceae), Aristholochia macroura Gomez (Aristholochiaceae), Stigmaphyllon paralias A. Juss (Malpighiaceae) and Bactris setosa Mart. (Arecaceae). There are also many species of Sapindaceae, Myrtaceae (at least four species), Solanaceae and Lauraceae (two species), all situated inside the sampling units.

\subsection{Observations and biometry}

Before measuring and counting the burrows, we needed to certify which were $C$. guanhumi burrows. It took several trips to be found the ideal conditions for activity of crabs. In periods of high activity, $C$. guanhumi were not so shy and could be observed near its burrows. For the observation of active crabs, we made inroads in the field during the afternoon in the summer months. Approximation to the burrows occurred slowly. Moving closer, the crabs entered the burrows but often remained visible. When the amount of crabs was excessive, it was necessary to wait some ten minutes until they returned to the surface to be counted. It was necessary not to make any movement at this moment.

The approximate location of crabs was plotted on a displayed aerial image of the resort. Drawings and diagrams were used to locate the burrows occupied in relation to several landmarks with known location. Two measuring tapes were used to verify if occupied burrows were contained inside the sampling units of $3,000 \mathrm{~m}^{2}$. For more precise analysis, measurements were made in smaller areas (Figure 2). In specific moments of the year, the largest crabs became easy to catch manually. This period is similar to the phenomenon of "andada" described for U. cordatus (Dias-Neto, 2010). Whenever possible, these crabs were captured, and the carapace widths were measured.

\subsection{Sampling units}

We utilised sample units with two sizes, comprising two distinct samples data. The first sample collection was composed of units with area of $3,000 \mathrm{~m}^{2}$ (Figure 1). We searched in 20 sampling units (totalling $90,000 \mathrm{~m}^{2}$ ) located in grassy area, and one sampling unit located in the forested area. The goal of this sampling strategy is to define de pattern of clustering of crabs and its relationship with the distance from the channel water. In this case, we utilised a high resolution map, plotting the occupied burrows. The sampling units were organised according to the distance from the water. Each degree of distance of water $(0-30 \mathrm{~m}$, 


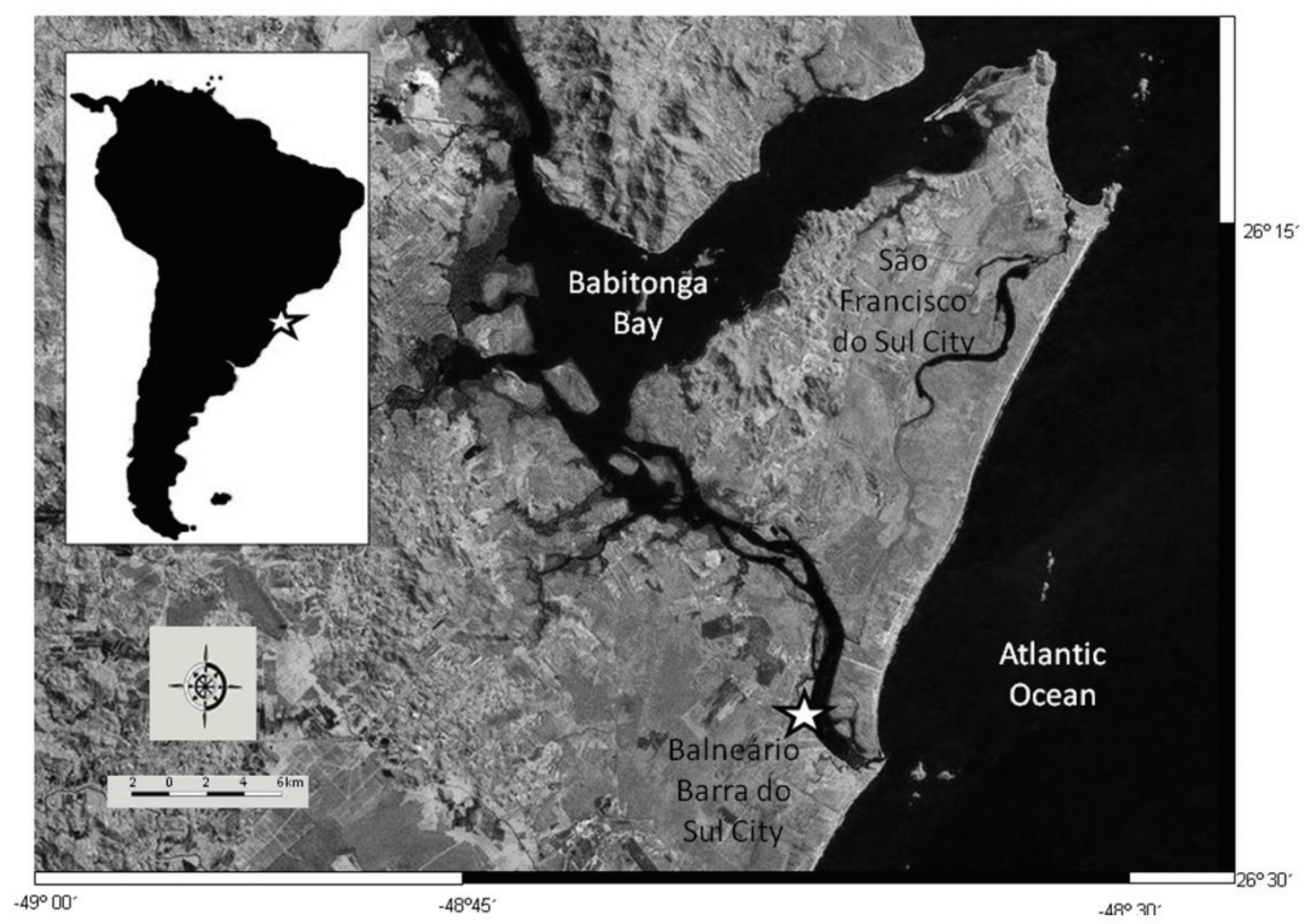

Figure 1. Sample location (stars) on the map of South America and in Babitonga bay.

Table 1. Number of samples of each combination of sample type, ecosystem and distance from water. Shaded areas correspond to Grassy/garden samples.

\begin{tabular}{|c|c|c|c|}
\hline Sample type & Ecosystem & $\begin{array}{c}\text { Distance from floodable } \\
\text { area }(\mathrm{m})\end{array}$ & Replicate number \\
\hline \multirow{6}{*}{$3000 \mathrm{~m}^{2}$} & \multirow{5}{*}{ Grass } & $0-30$ & 5 \\
\hline & & $30-60$ & 5 \\
\hline & & $60-90$ & 5 \\
\hline & & $90-120$ & 5 \\
\hline & & $120-150$ & 5 \\
\hline & Forest & $0-30$ & 1 \\
\hline \multirow{7}{*}{$12 \mathrm{~m}^{2}$} & \multirow{3}{*}{ Grass } & $0-6$ & 14 \\
\hline & & $6-12$ & 14 \\
\hline & & $12-18$ & 14 \\
\hline & \multirow{4}{*}{ Forest } & $0-6$ & 7 \\
\hline & & $6-12$ & 7 \\
\hline & & $12-18$ & 7 \\
\hline & & $18-24$ & 4 \\
\hline
\end{tabular}

30-60m, 60-90m, 90-120m) contained five sampling units (A, B, C, D, E are replicates of grassy area samples and F is the sample of the forested area) (Table 1).

The second sample collection was applied for smaller areas (Table 1), which were mapped with a more accurate technique described by Borzone et al. (2005). Two fixed points (A and B) were marked at 14 metres from the waterline towards the interior of the forest. These points
(A and B) were $14.5 \mathrm{~m}$ apart. We measured the distance of each burrow $(C)$ to points $A$ and $B$. Each burrow had three measurements that correspond to the sides of a triangle. It was possible to infer the lateral distance (y) and the distance from water (14-x) using the formula, $x=A C * \cos$ (A) and $y=A C * \sin (A)$. Thus, it was possible to plot the distribution of burrows in a map with precision (Figure 2). This method was applied in areas with high density of 


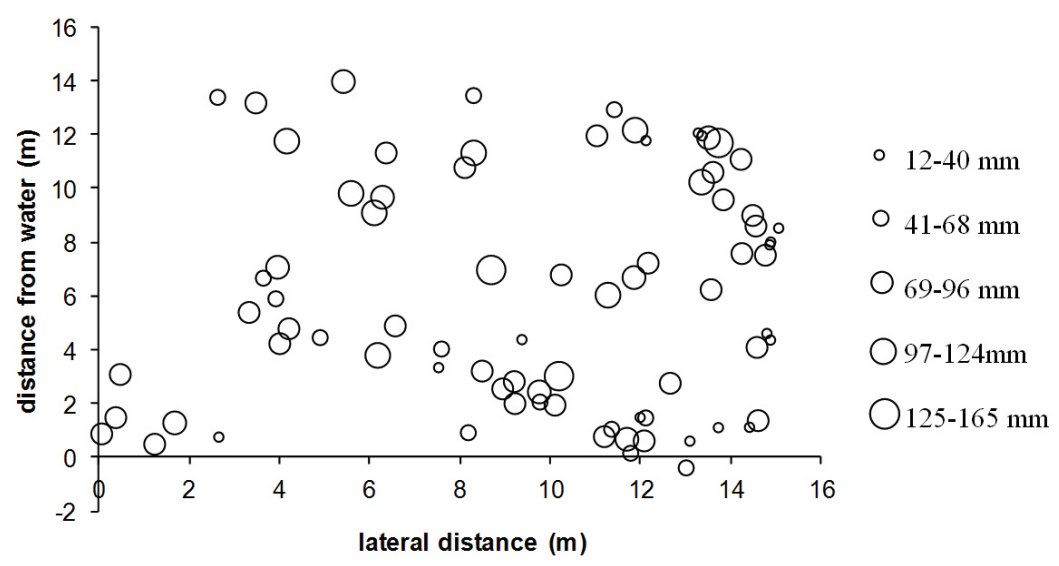

Figure 2. Mapping of burrows in the forest area. The symbol size represents the diameter of the burrows. The distances showed on the abscissa axis do not include the first three metres near the water.

burrows, with the goal of analysing the relation between size and distribution pattern with the type of ecosystem or distance from water, and burrow size.

For statistical analysis, we divided the produced map into sampling units of $12 \mathrm{~m}^{2}$ each. We used the KruskalWallis test to compare diameter of burrows (diameter with a caliper rule using the ramp entrance as reference) located at different distances from the water or in different ecosystems type. We also searched for the dispersion pattern for this scale. These sampling units were located at different distances from the water $(6 \mathrm{~m}, 12 \mathrm{~m}, 18 \mathrm{~m}$ or $24 \mathrm{~m}$ ). Sampling units located at the same distance from the water were considered replicates.

\subsection{Index of Dispersion}

Dispersion of the population was classified through a calculation of the variance to mean ratio; namely: $S^{2} / m=1$ random, $<1$ regular and $>1$ aggregated. Departure from a random distribution can be tested by calculating the index of dispersion (Ip), where $n$ denotes the number of samples: $I p=(n-1) S^{2} / m$. Values of $I p$ which fall outside a confidence interval bounded with $n-1$ degrees of freedom and selected probability levels of 0.95 and 0.05 , for instance, would indicate a significant departure from a random distribution. This index can be tested by $Z$ value as follows:

$\mathrm{Z}=(2 \times I p)^{0,5}-(2(\mathrm{n}-1)-1)^{0,5}$

If $-1.96>Z<1.96$, the spatial distribution would be random, but if $Z<-1.96$ or $Z>1.96$, it would be uniform and aggregated, respectively (Patil and Stiteler, 1974).

\section{Results}

\subsection{Sampling units with $3000 \mathrm{~m}^{2}$ (occupation)}

We count more than 300 crabs in a searching area of $93000 \mathrm{~m}^{2}$. Two hundred and ninety crabs were found in a unique sample site of $3000 \mathrm{~m}^{2}$ in the forest (Table 2). In other words, 190 crabs were found in a searching area 25 times broader in the grassy area. Indeed, eleven of these suitable sample sites were not occupied. The density varied according to the type of ecosystem and the distance from the channel. The higher population density was found in the forested sample, with 966 crabs by $\mathrm{km}^{2}$. In the grassy area, the first thirty metre counting from the channel had a population density of 25 crabs by $\mathrm{km} 2$ (Table 2 ). Population density decreased gradually following the increase of distance from the channel and no crabs were found at distances higher than $150 \mathrm{~m}$ from the channel, except one. This exception was found at $400 \mathrm{~m}$ from the channel, beside a river.

The index of dispersion was much higher (with values of $\mathrm{Z}$ indicating grouped pattern) in the sample group that lies between $0-30 \mathrm{~m}$ and $30-60 \mathrm{~m}$, indicating that in those areas where abundance were high, occupied places are still very limited (Table 2 ).

\subsection{Sampling unit with $12 m^{2}$ (size, density and dispersion)}

We searched in areas of $1128 \mathrm{~m}^{2}$ (38 sampling units) and counted 171 burrows. Density was higher in the forested area in the sampling units near channel $\left(0.43\right.$ crabs by $\left.\mathrm{m}^{2}\right)$ and gradually decreased following the distance increasing (Table 2). In the grassy area, we didn't observe this inversed correlation. The mean of density was the same in the sampling units near channel $(0-6 \mathrm{~m})$ and in the samples located between $12-18 \mathrm{~m}\left(0.21 \mathrm{crabs} / \mathrm{m}^{2}\right)$, and was smaller between $6-12 \mathrm{~m}(0.11 \mathrm{crabs} / \mathrm{m} 2)$. Index of dispersion was lower in the Forest, and not significantly different from a random distribution $(-1,96>\mathrm{Z}<1,96)$ of burrows at the distances of $0-6 \mathrm{~m}$ and $6-12 \mathrm{~m}$, but slightly clustered at the distance of $12-18 \mathrm{~m}$. The same index reveals the burrows are much more clustered in the grassy area, with values varying between 9 and 20, and $Z$ values above 5 (Table 2).

The Kruskal-Wallis test showed that there are significant differences between burrow size located in the forest from those located in the grassy area (Figure 3, Table 2). In the forest, burrows tend to be much larger in all comparisons. We 
Table 2. Values of abundance, dispersion and density, in each degree of distance of water and type of ecosystem. Bold numbers correspond to aggregated distribution pattern.

\begin{tabular}{|c|c|c|c|c|c|c|}
\hline & Distance (m) & $\begin{array}{c}\text { crabs by } \\
\text { sample unit } \\
\left(3000 m^{2}\right)\end{array}$ & DV & $\begin{array}{c}\text { Index of } \\
\text { dispersion }\end{array}$ & $\mathbf{Z}$ & $\begin{array}{c}\text { density (crabs/ } \\
\mathbf{m}^{2} \text { ) }\end{array}$ \\
\hline \multirow[t]{3}{*}{ Forest } & $0-30$ & 240 & 0 & & & 0.8 \\
\hline & $0-30$ & 22 & 19.0 & 16.4 & 8.8 & 0.007 \\
\hline & $30-60$ & 12 & 15.1 & 19.0 & 9.7 & 0.004 \\
\hline \multirow[t]{5}{*}{ Field } & $60-90$ & 5.5 & 7 & 8.9 & 5.8 & 0.002 \\
\hline & $90-120$ & 1.2 & 1.1 & 1.0 & 0.2 & 0.0004 \\
\hline & $120-150$ & 0.6 & 1.3 & 2.8 & 2.1 & 0.0002 \\
\hline & Distance $(\mathrm{m})$ & $\begin{array}{l}\text { crabs by } \\
\text { sample unit } \\
\left(12 \mathrm{~m}^{2}\right)\end{array}$ & DV & $\begin{array}{l}\text { Índex of } \\
\text { dispersion }\end{array}$ & Z & $\begin{array}{l}\text { density (crabs/ } \\
\mathrm{m}^{2} \text { ) }\end{array}$ \\
\hline & $0-6$ & 5.14 & 2.03 & 0.8 & -0.2 & 0.43 \\
\hline \multirow[t]{3}{*}{ Forest } & $6-12$ & 3 & 2.27 & 1.7 & 1.2 & 0.25 \\
\hline & $12-18$ & 1.29 & 2.05 & 3.3 & 2.9 & 0.11 \\
\hline & $0-6$ & 2.5 & 6.36 & 16.2 & 8.9 & 0.21 \\
\hline \multirow[t]{2}{*}{ Field } & $6-12$ & 1.29 & 3.40 & 8.9 & 5.4 & 0.11 \\
\hline & $12-18$ & 2.5 & 7.00 & 19.6 & 10.3 & 0.21 \\
\hline
\end{tabular}

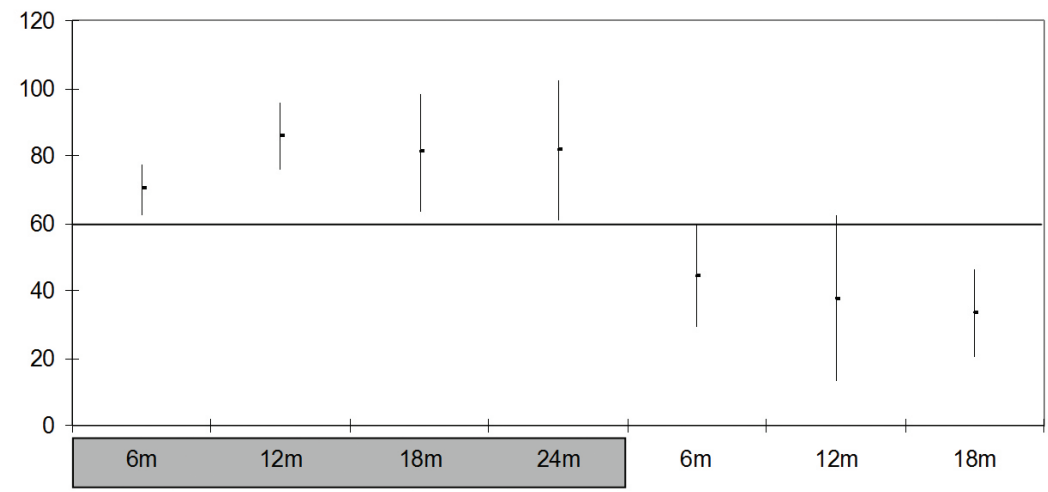

Figure 3. Mean of size of burrows (axis y) from sample set 2. Shaded rectangles involve forested locations and the three locations in the right are grassy areas. Numbers increase according to the degree of water distance. The horizontal line divides points in two groups. Points in the same group are not significantly different from others in the same group, but are significantly different from points from the opposite group. Test used: Kruskal- Wallis. $(\mathrm{p}<0,05)$.

did not detect differences in burrow size between different distance ranges of the same type of environment. Indeed, differences between sampling units of grassy areas from the forest samples located near the water were smaller than other comparisons.

A total of 34 individuals were measured over the time of this study. Twenty five males were found outside their burrows or dead, thirteen of which possess a carapace length longer than $8 \mathrm{~cm}$, and five with carapaces longer than $10.5 \mathrm{~cm}$. Seven females were attracted outside their burrows, and two were measured during a spawning event. Only one had a carapace length longer than $8 \mathrm{~cm}$.

\section{Discussion}

The forested population density was much higher than in the grassy area, and the average size of burrows was also higher. This information suggests that $C$. guanhumi had better conditions in the forested area, and that this was primarily its natural ecosystem in the region. This population is not derived from a recent colonisation of an altered ecosystem. The destruction of this small forested 
fragment could promote the extermination of this species in all studied site by suppression of main larval source. More studies focussing on the recolonisation by pelagic larvae are still required to preview the consequences of suppression of the great part of the population.

It was evident that the dispersion index was higher in grassy areas because suitable habitats were more restricted there, where crabs form groups along underground sewer pipes or near lamposts and small trees. They have additional benefits staying near lamposts because they are able to catch insects attracted by the light as observed in situ. In the forested areas, these burrows are less densely packed. C. guanhumi population tends to suffer a reducing process in grass, probably because there is high temperature variance and restricted access to ground water in this site (Govender et al., 2008). The same phenomenon was verified in our study. However, our research suggests that crabs are capable of finding restricted sites in the grassy area, such as in the underground sewer pipes.

The dense agglomeration of crabs in the grassy areas is facilitated by the fact that the diameter of burrows is usually smaller than those from the forest area. Smaller crabs may easily share a smaller space. According to Hill (2001), due to the agonistic behaviour of the species, the burrows are located far apart from each other. Probably, the best places were chosen by the stronger crabs, and the small crabs had to share places unacceptable for the larger ones. We also tried to identify similar populations of C. guanhumi in the Paranagua Bay Estuarine Complex and Guaratuba Bay, located north from the Linguado channel. However, we did not find aggregations as large and as accessible. We still do not know why $C$. guanhumi was attracted to this region. Although C. guanhumi seems to have adapted to a new situation (human occupation), deforested areas are still less appropriate to its conservation than minimal endangered forested areas.

It was not possible to infer objectively if this southern population is different in crab size from the northeastern population described by Botelho et al. (2001). Our capture method was occasional and involuntarily selects the large crabs in the region, although Botelho et al. (2001) used a different technique and captured juveniles or pre-adults in most cases. Considering that crabs with carapace width higher than ten centimetres were found accidentally or with little effort, the occurrence of large crabs can be considered a common phenomenon in this region. Additionally, the population found in Linguado Channel were larger than we expected for a subtropical population. The characteristics of the Linguado channel population, located just one hundred kilometres from its southern limit, suggests that the population is perfectly adapted to subtropical climate up to a limit located between Linguado channel and Itacorumi estuary. Santa Catarina is the final point for many species or ecosystems, like Mangroves and many of its inhabitants. Santa Catarina state is the southern limit of Mangrove forests, probably because it is very prejudiced by frost (Costa and Lavy, 1992). The lost of this ecosystem has contributed to the disappearance of other species that depend on it, such as U. cordatus. However, C. guanhumi was found in a site in Linguado channel that is not coverd by mangrove forests at its margins, which suggests that its presence does not necessarily need this type of ecosystem. Adults are capable of supporting extreme conditions of acidity, oxygenation and salinity (Pinder and Smits, 1993), but little is known about its larval tolerance of temperature. The resistance of its larvae to small temperatures needs to be evaluated. In laboratory conditions, all Larvae died at $20^{\circ} \mathrm{C}$ but survived well at $25^{\circ} \mathrm{C}$ (Costlow Jr and Bookhout, 1968). Temperatures in Santa Catarina lie between these two values in spawning months, which means that mortality of larvae could be the main factor that limits the occurrence of C. guanhumi in southern Brazil.

\section{References}

AMARAL, ACZ. and JABLONSKI, S., 2005. Conservação da biodiversidade marinha e costeira no Brasil. Megadiversidade, vol. 1 , no. 1 , p. 43-51.

BORZONE, CA., NETTO, JPB., PEYRER, L., BALDAN, LT., NOGUEIRA JUNIOR, M., SILVA, PRS. and METRI, R., 2005. Un método simple de estudiar la distribución espacial de Ocypode quadrata (Crustacea, Decapoda, Ocypodidae) en playas arenosas. In Anais do XI Congreso Latinoamericano de Ciencias del Mar, 2005. Valparaíso.

BRANCO, JO., 1991. Aspectos Ecológicos dos Brachyura (Crustacea: Decapoda) no Manguezal do Itacorubi, SC - Brasil. Revista Brasileira de Zoologia, vol. 7, p. 165-179.

Brasil. Ministério do Meio Ambiente, 2004. Instrução Normativa $\mathrm{n}^{\circ}$ 5, de 21 de maio de 2004. Lista Nacional das espécies de invertebrados aquáticos e peixes sobre-explotadas ou ameaçadas de sobre-explotacão. Diário Oficial da República Federativa do Brasil, maio. Available from: <http://www.ibama.gov.br/sisbio/ legislacao.php?id_arq $=28>$.

-, 2005. Centro de Pesquisa e Gestão de Recursos Pesqueiros do Litoral Nordeste. Boletim estatístico da pesca marítima e estuarina do nordeste do Brasil-2004. Tamandaré: CEPENE. Available from: $<$ www.ibama.gov.br/cepene/download.php?id_download=316>.

COSTA, CS. and DAVY, AJ., 1992. Coastal saltmarsh communities of Latin America. In SEELIGER, U. (Ed.). Coastal Plant Communities of Latin America. San Diego: Academic Press. cap. 12, p. 179-199.

COSTLOW JUNIOR, JD and BOOKHOUT, CG., 1968. The Effect of Environmental Factors on Development of the LandGrab, Cardisoma guanhumi Latreille. American Zoology, vol. 8, no. 3, p. 399-410. http://dx.doi.org/10.1093/icb/8.3.399

DIAS-NETO, J., 2010. Proposta de plano nacional de gestão para uso sustentável do caranguejo-uçá, do guaiamum e do siri-azul. IBAMA. $156 \mathrm{p}$.

GIFFORD, CA., 1962. Some observations on the general biology of the land crab, Cardisoma guanhumi (Latreille) in South Florida. Biological Bulletin of the Marine Biology Laboratory Woods Hole, vol. 123, p. 207-223.

GOVENDER, Y., SABAT, AM. and CUEVAS, E., 2008. Effect of land use/land cover changes on land crab, Cardisoma guanhumi, 
abundance in Porto Rico. Journal of Tropical Ecology, vol. 24 , no. 4, p. 417-423.

HILL, K., 2001. Cardisoma guanhumi. Smithsonian Marine Station at Fort Pierce.

HOSTETLER, ME., 2003. Blue Land Crab (Cardisoma ganhumi). Institute of Food and Agricultural Sciences, University of Florida.

LLOYD, RM., 2001. The Illusive Great Land Crab. Regional Perspectives in marine biology. Florida Community College at Jacksonville.

MELO, GAS., 1996. Manual de identificação dos Brachyura (caranguejos e siris) do litoral brasileiro. São Paulo: Plêiade. 604 p.

OLIVEIRA, ER., 2001. Aspectos populacionais do guaiamum (Cardisoma guanhumi Latreille, 1825), do estuário do rio Una (Pernambuco - Brasil). Boletim Técnico Cientifico do CEPENE/ IBAMA , vol. 9, no. 1, p. 123-146.

OLIVEIRA, LPH., 1946. Estudos ecológicos dos crustáceos comestíveis uçá e guaiamú, Cardisoma guanhumi Latreille Ucides cordatus (L). Gecarcinidae, Brachyura. Memórias do Instituto Oswaldo Cruz, vol. 44.
PEEL, MC., FINLAYSON, BL. and McMAHON, TA., 2007. Updated world map of the Köppen-Geiger climate classification. Hydrology Earth System Science, vol. 11, p. 1633-1644. http:// dx.doi.org/10.5194/hess-11-1633-2007

PINDER, AW and SMITS, AW., 1993. The analysis of ambiental conditions inside the burrows (The Burrow Microhabitat of the Land Crab Cardisoma guanhumi: Respiratory/Ionic Conditions and Physiological Responses of Crabs to Hypercapnia. Physiological Zoology, vol. 66, no. 2, p. 216-236. RODRIGUEZ-FOURQUET, C., 2002. Effect of fishing on the land crab's (Cardisoma guanhumi) density and size structure in Puerto Rico. University of Puerto Rico: San Juan.

SILVA, R. and OSHIRO, LMY., 2002. Aspectos da reprodução do caranguejo guaiamum, Cardisoma guanhumi Latreille (Crustácea, Decapoda, Gecarcdinidae) da Baía de Sepetiba. Rio de Janeiro, Brasil. Revista Brasileira de Zoologia, vol. 19, p. 71-78. http:// dx.doi.org/10.1590/S0101-81752002000600007

WEDES, S., 2004. Cardisoma guanhumi. Animal Diversity Web. University of Michigan Museum of Zoology. 